\title{
Weighing the Evidence on the Relation between External Corporate Financing Activities, Accruals and Stock Returns
}

\author{
Daniel A. Cohen, Thomas Z. Lys ${ }^{* *}$
}

April 18, 2006

Stern School of Business, New York University, New York 10012

Kellogg School of Management, Northwestern University, Evanston, Illinois 60208

\begin{abstract}
Bradshaw, Richardson, and Sloan (BRS) find a negative relation between their comprehensive measure of corporate financing activities and future stock returns and future profitability. Noticing that accounting accruals are increases in net operating assets on a company's balance sheet, we question whether it is possible to distinguish between the 'external financing anomaly' documented by BRS and the 'accrual anomaly' first documented by Sloan (1996). We show that once controlling for total accruals, the relation between external financing activities and future stock returns is attenuated and not statistically significant. These findings are consistent with Richardson and Sloan (2003).
\end{abstract}

JEL classification: G10, M4

Keywords: External financing; Analysts'forecasts; Accruals; Capital Markets; Market Efficiency.

* We would like to thank Jieying Zhang for helpful comments. All remaining errors are our own responsibility.

** Corresponding Author (847) 491-2673, tlys@kellogg.northwestern.edu 


\section{Introduction}

Bradshaw, Richardson, and Sloan (2006, hereafter BRS) examine the relation between firms' external financing activities, future stock returns, future profitability and analysts' forecasts. BRS summarize that, "The key innovation of our research design is the use of statement of cash flows data to construct a comprehensive and parsimonious measure of the net amount of cash generated by corporate financing activities" (page 1). In other words, BRS' major contribution is their focus on net external financing activities rather than individual components of corporate financing activities (e.g., debt versus equity) chosen by firms. In addition to investigating future stock returns and profitability following firms' corporate financing activities, BRS analyze analysts' short-term and long-term earnings forecasts, growth forecasts, stock recommendations, and target prices. Overall, BRS ask an interesting and intriguing question that goes beyond the traditional pecking-order theory.

Their primary findings are that there exists a negative and statistically significant relation between net external financing and future stock returns, and future profitability, and a positive relation with optimism in analysts' forecasts. These results, in turn, imply that the relevant information in financing activities is that the firm raised (or repaid) funds, rather than the specific means by which the firm raised (e.g., debt versus equity) or repaid (dividends and stock repurchases versus interest and repayment of debt) funds.

Using a trading strategy based on the overall measure of net external financing, BRS document that such a hedge portfolio generates an annual return of $15.5 \%$. This return exceeds the hedge portfolio returns based on the individual components of net external financing. The overall results on the relation between external financing and future stock 
returns and future profitability imply that investors do not correctly infer the negative relation between financing activities and future performance.

BRS investigate both investors' and analysts' responses to firms' financing activities. Their research is designed to distinguish between risk and misvaluations as potential explanations for the association between future stock returns and firms' corporate financing activities. They find a systematic positive relation between net external financing and optimism in analysts' forecasts. Furthermore, the results suggest that analysts' optimism is related to the type of security issued: over-optimism for debt issuance is restricted to short-term earnings forecasts, while over-optimism for equity issuance is also related to long-term earnings forecasts, growth, stock recommendations and target prices. The above findings lead BRS to conclude that analysts play a 'central role' in the overpricing of security issuances.

Based on their findings, BRS offer the following interpretations and implications:

(i) “... consistent with the misvaluation hypothesis, the predictable stock returns are directly related to predictable errors in analysts' earnings forecasts .... Overall, the results are consistent with the hypothesis that firms time their corporate financing activities to exploit the temporary misvaluation of their securities in capital markets."

(ii) “... our results suggest that the negative stock returns following new security issuances are primarily attributable to firm misvaluations rather than wealth transfers between stockholders and bondholders ... we show that changes in debt are negatively related to future returns. This evidence is consistent with the firm misvaluation hypothesis, but inconsistent with the wealth transfer hypothesis."

(iii) “... analysts could self-select into covering the particular issuing firms that they naively forecast to have the best future prospects. Second, management could self-select into issuing securities during periods in which their inside information indicates that analysts' forecasts are most optimistic. Third, conflicts stemming from incentives to generate investment banking and/or brokerage business could lead analysts to intentionally bias their forecasts." 
By design, however, BRS' analysis is closely related to the 'accrual anomaly' literature: the cash flow identity implies that financing and operating cash flows are negatively related. Moreover, operating cash flows equal net income minus accruals. In other words, accounting accruals are increases in the amount of net operating assets on a company's balance sheet. As a result, it is important to establish whether BRS's findings complement or subsume the results of the 'accrual anomaly' (Sloan, 1996). Consequently, our discussion focuses on two key questions: (1) whether financing per se rather than the specific financing vehicles chosen matter, and (2) whether the results differ from what is known and has been referred to as the 'accrual anomaly.'

Section 2 discusses the analysis of BRS. The sample selection is presented in Section 3. Section 4 focuses on the relation between external financing activities and accruals whereas the relation between financing activities and future performance is discussed in Section 5. Section 6 discusses the relation between analysts' forecast properties and external financing activities. Conclusions and suggestions for future research are presented in Section 7.

\section{Research Design}

BRS divide their analyses into three parts. First, the authors examine how investors respond to firms' choices of raising capital. Second, BRS investigate whether external financing activities are related to fundamental variables as evidenced in future profitability. The third part of the analysis focuses on the relation between analyst forecast properties and firms' external financing activities. 
Net amount of cash flows received from external financing activities $(\triangle X F I N)$, the central part of BRS's analysis is defined as:

$$
\Delta X F I N_{t}=\Delta E Q U T Y_{t}+\Delta D E B T_{t}
$$

where $\triangle E Q U I T Y(\triangle D E B T)$ represents net cash received from the sale and/or purchase of common and preferred stock less cash dividends paid (net cash received from the issuance and/or reduction of debt). Under the Modigliani and Miller assumptions (1958, $\mathrm{M} \& \mathrm{M}$ ), financing activities have no impact on firm value. However, when the M\&M assumptions are relaxed, firms' external financing activities provide information on the operating cash flows and on investment opportunities of the firm. In the former case, unexpected external financing is likely to be interpreted that current and future cash flows are not sufficient to allow the firm to invest. Hence, it will be interpreted by investors as 'bad news.' On the other hand, external financing can also be indicative of increased investing activities. Since on average managers accept positive net present value projects (McConnell and Muscarella, 1985) increases in financing can be interpreted as a positive signal by capital markets investors. Finally, the mix of financing activities provides information regarding insiders' beliefs on whether the current stock price is overvalued or undervalued (see Frank and Goyal, 2003; Myers, 1984; and Sunder and Myers, 1999 for a detailed analysis and discussion on the pecking order theory of capital structure).

BRS' analysis is centered on six propositions that follow from their misvaluation hypothesis. Evidence on the first three propositions is provided in their Table 5. Panel A reports the results for $P 1$ (i.e., there is a negative relation between net external financing and future stock returns) by estimating:

$$
\operatorname{SRET}_{t+1}=\gamma_{0}+\gamma_{1} \Delta \operatorname{XFIN}_{t}+v_{t+1}
$$


Panel B of Table 5 reports evidence on propositions $P 2$ (i.e., there is a negative relation between marginal changes in equity financing and future stock returns) and $P 3$ (i.e., there is a negative relation between marginal changes in debt financing and future stock returns) by estimating:

$$
\begin{gathered}
\operatorname{SRET}_{t+1}=\gamma_{0}+\gamma_{1} \Delta E Q U T Y_{t}+v_{t+1} \\
\operatorname{SRET}_{t+1}=\gamma_{0}+\gamma_{2} \Delta D E B T_{t}+v_{t+1}
\end{gathered}
$$

and

$$
\operatorname{SRET}_{t+1}=\gamma_{0}+\gamma_{1} \Delta E Q U T Y_{t}+\gamma_{2} \Delta D E B T_{t}+v_{t+1}
$$

where $S R E T_{t+1}$ is the annual size-adjusted stock return. As Table 5 indicates, the evidence is consistent with the first three research propositions: the slope coefficients of $\triangle X F I N, \triangle E Q U I T Y$, and $\triangle D E B T$ are all negative and statistically significant at conventional levels.

While these results are very compelling, two questions remain unanswered by BRS: (1) how do those results relate to the accrual anomaly, and (2) what is the information provided by the specific choices of financing (debt and equity) chosen relative to the information provided by external financing $(\triangle X F I N)$. If, in fact, $\triangle X F I N$ is a "comprehensive and parsimonious measure of the net amount of cash generated by corporate financing activities" then the coefficients of $\gamma_{1}$ and $\gamma_{2}$ in the last row of Panel B of Table 5 should be approximately equal (which they do not appear to be - in section 4 we show that they are not). Alternatively, under the pecking order theory, the coefficient of $\triangle E Q U I T Y$ should be smaller (more negative) than the coefficient of $\triangle D E B T$. Moreover, most of the variation in regressions (2) and (3) should be explained by $\triangle X F I N$ and not by the proportion of debt and equity issued. 
In Table 6, BRS provide corroborating evidence by documenting that subsequent earnings (for the subsequent year and for period $t+2$ through $t+5$ ) are negatively related to both $\triangle X F I N$ and to $\triangle E Q U I T Y$, and $\triangle D E B T$. This evidence is consistent with the results of Table 5: both $\triangle X F I N$ and its components, $\triangle E Q U I T Y$ and $\triangle D E B T$, are associated with negative subsequent performance. Hence, the picture that emerges is that investors fail to take this association between both $\triangle X F I N$ and its components, $\triangle E Q U I T Y$ and $\triangle D E B T$, when pricing securities into account. We further discuss these specific findings and provide an alternative interpretation in Section 4.

Further corroborating evidence is provided in Tables 7, 8, and 9 where BRS document that short and long-term earnings forecasts of sell side analysts fail to incorporate the relation between external financing activities and subsequent performance. While the evidence presented in BRS is compelling, the remainder of our discussion focuses on the specific interpretation given by BRS and whether the evidence documented is distinct from the accrual anomaly.

\section{Sample Selection and Variable Measurement}

To investigate whether net external financing activities as measured by BRS are related to accounting accruals, we employ accrual metrics used in the literature. Given the shortcomings associated with each individual empirical measure of accruals (e.g., Collins and Hribar (2002), Dechow et al. (2004)), we employ multiple measures and are agnostic about the relative superiority of those metrics. 


\subsection{Sample Selection}

To supplement BRS' analysis, we selected a sample following their procedures as closely as possible. (Please consult the Appendix for a summary of variable definitions.) From the 2005 COMPUSTAT annual tapes we select all firm-year observations with available data for the period 1971-2004. We exclude firm-year observations with missing data on COMPUSTAT to compute our main financial statement variables. In addition, we also exclude firms in the financial service industries (SIC code 6000-6999) since accruals for these firms are difficult to interpret.

As in BRS, we measure the net amount of cash flows received from external financing activities $\triangle X F I N$, as: $\triangle X F I N=\triangle E Q U I T Y+\triangle D E B T . \quad \triangle E Q U I T Y$ is net equity financing measured as the proceeds from the sale of common and preferred stock (COMPUSTAT item \#108) less cash payments for the purchase of common and preferred stock (COMPUSTAT item \#115) less cash payments for dividends (COMPUSTAT item \#127). $\triangle D E B T$ is net debt financing measured as the cash proceeds from the issuance of long-term debt (COMPUSTAT item \#111) less cash payments for long-term debt reductions (COMPUSTAT item \#114) less the net changes in current debt (COMPUSTAT item \#301). To be consistent with BRS, we require the availability of COMPUSTAT data for each one of the above variables, with the exception of data item \#301, which we set to zero, if it is missing. As in BRS, we scale these variables by average total assets and delete firm-year observations with an absolute value greater than 1. These criteria yield a primary sample of 144,025 firm-year observations for the period 1971-2004, and a sub-sample of 78,575 firm-year observations for 1988-2004. Based on the evidence of Collins and Hribar (2002) we use the statement of cash flows approach to calculate accruals for our 1988-2004 period sub-sample. 
Much of the accounting literature has employed a balance sheet approach to calculate the accrual component of earnings. The first measure of accruals we use is total accruals $\left(T \_A C C R\right)$ defined as the change in non cash assets [(change in COMPUSTAT item \#6) less the change in COMPUSTAT item \#1)] less the change in non-debt liabilities (change in COMPUSTAT item \#181 less the change in COMPUSTAT item \#9 less the change in COMPUSTAT item \#34). We use this extended measure of total accruals given the evidence and discussions in Dechow et al. (2004), Richardson et al. (2005), and Richardson et al. (2006). In particular, the above studies argue that most definitions of accruals employed in the existing literature focus on the change in non-cash working capital adjusted for depreciation expense. As such, they omit many accruals that relate to non-current operating assets, non-current operating liabilities, non-cash financial assets, and non-cash financial liabilities (see for example, Richardson et al. (2005, p. 445-446)). Given the focus of the BRS study on external financing activities, the extended and comprehensive measure of total accruals $\left(T_{-} A C C R\right)$ is more suitable and relevant to our current discussion compared to other empirical measures of accruals.

The second measure of accruals $(A C C R)$ is defined as the change in current assets (COMPUSTAT item \#4) less the change in cash (COMPUSTAT item\#1) less the change in current liabilities (COMPUSTAT item \#5) plus the change in debt in current liabilities (COMPUSTAT item \#34) less depreciation (COMPUSTAT item \#14). The third measure of accruals $\left(A C C R_{-} C F\right)$ is based on annual data from the statement of cash flows, defined as earnings before extraordinary items from the statement of cash flows (COMPUSTAT item \#123) less cash flows from operations (COMPUSTAT item \#308). We calculate $A C C R \_C F$ only for the sub-period of 1988-2004, when the statement of cash flows data are available. 
In addition to accrual measures, we define free cash flows $(F C F)$ as in Dechow et al. (2004) to be equal to the difference between income before extraordinary items (COMPUSTAT item \#18) and total accruals $\left(T \_A C C R\right)$. CFO_BS is operating income after depreciation (COMPUSTAT item \#178) less $A C C R$. CFO_87 is cash flows from operations per the statement of cash flows (COMPUSTAT item \#308).

\subsection{Descriptive Statistics of the Variables Used}

Table 1 presents descriptive statistics and correlations for the external financing, accruals, earnings, and cash flows variables. In general, the descriptive statistics related to the various measures of accruals and cash flows are similar and consistent with those reported in prior research. For example, consistent with Dechow et al. (2004) we find that $T_{-} A C C R$ is positive with a mean (median) of $0.046(0.038)$ for the period 1971-2004 and 0.037 (0.029) for 1988-2004. Similar to prior research we find that mean $A C C R$ and $A C C R_{-} C F$ are negative (-0.046 and -0.078 , for 1988-2004), reflecting the depreciation charge included in this measure of accruals. The standard deviation of $T_{-} A C C R$ is 0.217 whereas the standard deviation of $A C C R$ is 0.139 (for 1971-2004) which reflects the different compositions of the accruals included in each of the above measures. The mean free cash flow $(F C F)$ is -0.067 with a standard deviation of 0.257 , which mirrors the findings in Dechow et al. (2004). Cash flows from operations are positive (0.069 for 1971-2004, and 0.020 for 1988-2004). We find that mean $\triangle X F I N$ is 0.041 , mean $\triangle E Q U I T Y$ is 0.028 and mean $\triangle D E B T 0.012$, which are smaller in magnitude compared to BRS, but follow the same relation. ${ }^{1}$

\footnotetext{
${ }^{1}$ BRS final sample includes analysts' earnings forecast data from I/B/E/S for the period 1971-2000, likely accounting for the differences. None of the specific tests we replicate are sensitive to employing this specific sample period in our discussion.
} 
Panels C and D in Table 1 report Pearson and Spearman correlation among our main variables of interest. Consistent with prior results, we find that the various measures of accruals are negatively correlated with the corresponding cash flows variables, both during 1971-2004 and for the sub-sample period of 1988-2004. Specifically, as in Dechow et al. (2004), we find a strong negative correlation between $T_{-} A C C R$ and $F C F$ (Pearson: -0.636, Spearman: -0.562) and a negative correlation between $A C C R$ and CFO_BS (Pearson: -0.318, Spearman: -0.381). Given the evidence in Collins and Hribar (2002), we analyzed a sub-sample, focusing on 1988-2004, where we find a negative correlation (Pearson: -0.085 , Spearman: -0.381) between $A C C R \_C F$ and $C F O \_87$.

Turning to the pair-wise correlations between the external financing variables and accruals we find, in general, a positive relation. In particular, we find a strong positive correlation between $\triangle X F I N$ and $T_{-} A C C R$ (Pearson: 0.346, Spearman: 0.353), as well as between $\triangle D E B T$ and $T \_A C C R$ (Pearson: 0.301, Spearman: 0.304), and $\triangle E Q U I T Y$ and T_ACCR (Pearson: 0.174, Spearman: 0.099).

Panel D of Table 1 reports pair-wise correlations for the sub-sample period of 19882004, a period in which cash flows statement data are available as well. Consistent with the correlations in Panel $\mathrm{C}$, we find a positive correlation between $\triangle X F I N$ and $T_{-} A C C R$ (Pearson: 0.277, Spearman: 0.277) as well as between $\triangle D E B T$ and $T_{-} A C C R$ (Pearson: 0.213, Spearman: 0.198), and $\triangle E Q U I T Y$ and $T_{-} A C C R$ (Pearson: 0.1674, Spearman: 0.123). The correlation between the external financing components and $A C C R \_C F$ does not provide the same picture. Although there is a weak positive correlation between $\triangle X F I N$ and $A C C R \_C F$ (Spearman: 0.034 ) and a positive correlation between $\triangle D E B T$ and $A C C R \_C F$ (Spearman: 0.025), the other pair-wise correlations are close to zero. Overall, the above correlations suggest that $T_{-} A C C R$, our total accruals measure, is strongly and 
significantly positively associated with the comprehensive measure of net external financing as well as with its components, regardless of the specific sample period analyzed. However, the correlation between net external financing and accruals is highly dependent on the specific definition of accruals employed.

\section{External Financing Activities and Accruals}

We investigate the relation between external financing and accruals by ranking the sample into 10 deciles by total accruals, $T_{-} A C C R$. Figure 1 and Table 2 Panel A document our findings. It is evident from both Figure 1 and Panel A that firms in the top total accruals deciles (deciles 7 to 10 ) are characterized by large values of net external financing. ${ }^{2}$ We repeat the ranking procedure for the sub-sample 1988-2004 and document similar findings in Figure 3. Figures 2 and 4 illustrate the findings when we rank the sub-sample (1988-2004) observations by $A C C R$ and $A C C R \_C F$. Both Figure 2 and Figure 4 suggest that firms in the top and bottom deciles exhibit high values of net external financing as well as $\triangle E Q U I T Y$.

The overall evidence in Figures 1-4 and Table 2 suggest that an alternative interpretation to the findings reported in BRS might be that the "external financing activities anomaly" documented by the authors is just a reflection of the well known and widely cited "accrual anomaly." This interpretation is not new. Zach (2003), exploring characteristics that cause or are correlated with extreme accruals, finds that extreme accrual firms are more likely to have experienced specific corporate financing events, such as initial public offerings, seasoned equity offerings, restructurings and divestitures.

\footnotetext{
${ }^{2}$ We calculate and report for each of the deciles the mean and median market value of equity. Table 2, Panel A suggests that the median market value of equity in the top deciles of total accruals (7-10) do not reflect primarily small firms which might be too illiquid to implement a hedging strategy.
} 
Given that these corporate events are known to be related to abnormal future stock returns, Zach (2003) examines to what extent the accrual anomaly overlaps with the external financing anomaly. He provides evidence suggesting that the accrual's hedge returns strategy decreases by $25 \%$ once he excludes mergers and divestitures.

In a related study, Richardson and Sloan (2003) provide evidence that the relation between net external financing and future stock returns is a function of the use of the cash proceeds obtained from corporate financing activities. They find that the negative relation between changes in external financing and future stock returns is strongest when the cash proceeds are invested in operating assets, suggesting that they are recorded as accounting accruals. In particular, Richardson and Sloan (2003) claim that:

"[These] results suggest that the external financing anomaly in stock returns is closely related to the accrual anomaly in stock returns documented by Sloan (1996), Fairfield et al. (2003) and Richardson et al. (2003). In fact we show that the accrual anomaly is much stronger than the external financing anomaly and that after controlling for accruals, the relation between external financing and future stock returns almost completely disappears. Our results suggest that the relation between external financing and future stock returns is most consistent with a combination of over- investments and aggressive accounting that are not anticipated by investors."

To investigate whether the accrual anomaly and the external financing anomaly are distinct, we test the association between future stock returns and $\triangle X F I N$ (the net external financing proxy) once we control for $T_{-} A C C R$ (total accruals). Panel A, Table 3 documents the results of a regression of future annual stock returns on $\triangle X F I N$ and $T \_A C C R$. Consistent with the results in BRS Table 5, we find that the coefficient on $\triangle X F I N$ is negative and statistically significant. Moreover, we find that the coefficient magnitude is 0.192 which is almost identical to the one documented by BRS $(0.200)$. When we test the association between future annual stock returns and $T \_A C C R$, we find the coefficient to be negative and highly statistically significant, consistent with existing research. Interestingly, once we include both $\triangle X F I N$ and $T \_A C C R$ in the regression, the 
coefficient on $T \_A C C R$ is still negative and highly statistically significant, whereas the coefficient on $\triangle X F I N$ decreases by more than $40 \%$ to -0.081 (as compared to -0.192 ) and is no longer statistically significant at conventional levels. This suggests, consistent with the evidence in Richardson and Sloan (2003) that the external financing anomaly no longer persists, once we control for the accrual anomaly. This result is not surprising as accounting accruals are increases in the amount of net operating assets on a company's balance sheet. Since accounting accruals represent the other side of the balance sheet from financing liabilities, a firm which has high accounting accruals (i.e., a large amount of net operating assets) is likely to have higher amounts of external financing.

Panel $\mathrm{B}$, Table 3 presents the results once we decompose $\triangle X F I N$ into $\triangle D E B T$ and $\triangle E Q U I T Y$. Consistent with the evidence in BRS, the coefficients on both components are negatively and statistically significant. However, we can reject the restriction that they are equal at conventional levels $(\mathrm{F}=217.19)$. However, consistent with the results in Panel A, Table 3, once we control for total accruals the external financing coefficients decrease in their magnitude and are no longer statistically significant at conventional levels.

These results, together with the findings in Richardson and Sloan (2003), suggest that the negative relation documented between net external financing activities and future stock returns is consistent with the over-investment hypothesis rather than with the market-timing hypothesis. ${ }^{3}$ In summary, our analysis, taken together with the discussion in Zach (2003) and Richardson and Sloan (2003), suggests that one has to consider

\footnotetext{
${ }^{3}$ Consistent with the existing literature we refer to an 'over-investment' hypothesis as a prediction in which firms which issue new securities tend to invest in value-destroying projects. Observing negative future stock returns after these securities issues suggests that the lower stock returns are a reflection of value destruction due to over-investments. The market-timing hypothesis suggests that firms will tend to issue securities when they are overvalued and repurchase securities when they are undervalued.
} 
whether the results reported by BRS are distinguishable from the well-known accrual anomaly first documented by Sloan (1996).

\section{External Financing and Future Performance}

In this section we discuss the relation between external financing activities and future earnings performance. In particular, we discuss the analysis of Table 6 in BRS. We first replicate BRS' Table 6, Panel C results. Consistent with BRS, we measure earnings performance as operating income after depreciation (COMPUSTAT item \#178) deflated by average total assets. In line with BRS we focus on 'long-term' measures of earnings performance over the four-year period starting one year after the external financing year and ending five years after the financing year.

The results in Table 6, Panel $\mathrm{C}$ raise the question whether the comprehensive net external financing measure $(\triangle X F I N)$ is a proxy for the shortfall of internal operating cash flows or whether it proxies for the firm's investment opportunities set. The analysis in Table 6, Panel $\mathrm{C}$ in BRS suggests that the coefficient estimate of $\triangle X F I N$ is negative, which is inconsistent with the investment opportunities interpretation (which would imply a positive coefficient). If the M\&M assumptions hold, financing activities should have no impact on firm value once the investment opportunities are held constant. To distinguish between the two possible explanations of the $\triangle X F I N$ proxy, we augment the analysis of BRS by replacing $\triangle X F I N$ with proxies for investments and operating cash flows. We report our results in Table 4.

Panel A reports results consistent with Table 6, Panel C in BRS, documenting a statistically significant negative relation between $\triangle X F I N$ and future earnings performance. However, the results in Panel B suggest that this relation is driven mainly 
by $\triangle E Q U I T Y$. Consistent with these results and interpretation in BRS, one can conclude that the negative relation between external financing activities is mostly due to equity financing. This suggests that "[the] overvaluation of equity is particularly sensitive to the overestimation of long-term profitability" (BRS, p.21).

In Panels $\mathrm{C}$ and $\mathrm{D}$ we provide further evidence on this result by investigating the relation between investments and operating cash flows and future performance. We distinguish between two sample periods: 1971-2004 (Panel C) and 1988-2004 (Panel D). In Panel $\mathrm{C}$ we define cash flows from investing activities, INVEST_BS as the sum of the proceeds from sale of PPE (COMPUSTAT item \#107) plus the proceeds from sale of investments (COMPUSTAT item \#109) less capital expenditures (COMPUSTAT item \#128) less acquisitions (COMPUSTAT item \#129) less the increase in investments (COMPUSTAT item \#113). INVEST_SCF is defined as net cash flows from investing activities per the statement of cash flows (COMPUSTAT item \#311). We multiply the investment variables by (-1) to make the interpretation of findings more intuitive. $C F O$ is cash flows from operations and is defined as operating income after depreciation (COMPUSTAT item \#178) less ACCR, for the period 1971-2004 (Panel C), and cash flows from operations per the statement of cash flows (COMPUSTAT item \#308) for the sub-sample 1988-2004 (Panel D). All variables are deflated by average total assets (COMPUSTAT item \#6).

The results in Panel C and D suggest that cash flows from operations are positively associated with future operating performance, whereas we find no significant relation between our investments proxies and future performance. We interpret these findings as consistent with the observation that cash flows generated from operating activities are positive indicators of future operating performance. 
Panels E and F document our findings when we augment the components of external financing variables, $\triangle E Q U I T Y$ and $\triangle D E B T$, with the cash flows from investments and cash flows from operations. In Table 4, Panel E we find that for the period 1971-2004, the previously documented significant negative relation between $\triangle E Q U I T Y$ and future performance persists, as well as a statistically significant positive relation between cash flows from operations and future performance. Although we find a positive relation between INVEST_BS and future performance, it is not statistically significant at conventional levels.

In Panel F we repeat the previous analysis for the sub-sample of 1988-2004, where we use data from the statement of cash flows to compute both the cash flows from investment activities and cash flows from operations. Consistent with the findings in BRS we find that there is statistically strong negative significant relation between $\triangle E Q U I T Y$ and future performance and a weaker (yet statistically significant) negative relation between $\triangle D E B T$ and future performance. In addition, Panel $\mathrm{F}$ shows that both cash flows from investing activities and cash flows from operations are statistically significantly associated with future performance. However, in both Panel E and F we reject the restriction that the coefficients for $\triangle E Q U I T Y$ and $\triangle D E B T$ are equal at the 1 percent level or better (with the coefficient for $\triangle D E B T$ often not achieving statistical significance). Thus, jointly, the results in Table 4 suggest that it is not $\triangle X F I N$ that is correlated with future performance but the composition of debt and equity used.

\section{External Financing and Analyst's Forecast Errors}

The last part of the BRS study examines whether the negative future stock returns relation is because investors do not anticipate the negative future performance 
phenomena. Given our discussion in Section 4 on the relation between external financing activities and accounting accruals, it is difficult to argue that investors, in general, and financial analysts in particular, do not incorporate into their expectations the predictable future earnings changes due to external financing activities. In other words, an unanswered question still remains whether the accrual anomaly is distinguishable from the external financing anomaly, and which one of the two phenomena (or a single phenomenon) investors seem to misinterpret. This is an especially important and relevant issue given the empirical evidence documented in Bradshaw et al. (2001) who show that analysts' earnings forecasts do not incorporate and anticipate the future problems associated with high accruals.

In the end, it is difficult to argue that financial analysts, as well as investors, do not anticipate the consequences of external financing activities, since we do not know whether the two related anomalies (the accrual anomaly and the external financing one) are mutually exclusive. Our earlier discussion and analysis taken together with the Richardson and Sloan (2003) study suggest that they might not be, and that the accrual anomaly dominates the external financing anomaly.

\section{Conclusions and Future Research}

As stated in the introduction, BRS' major contribution is the use of statement of cash flows data to construct a comprehensive and parsimonious measure of the net amount of cash generated by corporate financing activities and examine its relation with future stock returns, future performance and analysts' forecast properties.

This is an intriguing research endeavor and they provide some interesting results. However, our analysis raises the question of the interpretation of some of the results. In 
particular, we argue that it is difficult to distinguish between the well-documented accrual anomaly (Sloan, 1996) and the external financing anomaly which is the focus in BRS. How can one tease out the accrual anomaly effect and provide convincing evidence that the external financing anomaly is, indeed, a distinct phenomenon? This task still remains to be addressed.

We believe that the interplay between BRS' results and our discussion provide some clear avenues for future research. For example, BRS provide evidence that both investors and financial analysts seem not to fully incorporate the implications of firms' external financing activities into their expectations. A possible avenue for future research is to disentangle the influence of the analysts' overoptimistic forecasts from investors' assessments of the impact of firms' financing activities. Are these two observations simply the consequence of investors' reliance on analysts' forecasts or are these two distinct effects? 


\section{References}

Bradshaw, M., S.A. Richardson, and R.G. Sloan, 2001, "Do Analysts and Auditors Use Information in Accruals?" Journal of Accounting Research 39, 45-73.

Bradshaw, M., S.A. Richardson, and R.G. Sloan, 2006, "The Relation between Corporate Financing Activities, Analysts' Forecasts and Stock Returns," Journal of Accounting and Economics, this issue.

Collins, D., and P. Hribar, 2002, "Errors in Estimating Accruals: Implications for Empirical Research,” Journal of Accounting Research 40, 105-134.

Dechow, P. M., S.A. Richardson, and R.G. Sloan, 2004, "The Persistence and Pricing of the Cash Component of Earnings," Working Paper, University of Michigan and University of Pennsylvania.

Frank, M.Z., and V.K. Goyal, 2003, "Testing the Pecking Order Theory of Capital Structure," Journal of Financial Economics 67, 217-28.

McConnell, J. J., and C. J. Muscarella, "Corporate Capital Expenditure Decisions and the Market Value of the Firm," Journal of Financial Economics 14, 399-423.

Modigliani F. and M. H. Miller, 1958, "The Cost of Capital, Corporation finance, and the Theory of Investment," American Economic Review 48, 655-669.

Myers, S.C., 1984, “The Capital Structure Puzzle,” Journal of Finance 39, 575-592.

Richardson, S.A. and R.G. Sloan, 2003, "External Financing, Capital Investment and Future Stock Returns," Working Paper, University of Pennsylvania and University of Michigan.

Richardson, S.A., R.G. Sloan, M.T. Soliman, and I. Tuna, 2005, “Accrual Reliability, Earnings Persistence and Stock Prices," Journal of Accounting and Economics $39,437-485$.

Richardson, S.A., R.G. Sloan, M.T. Soliman, and I. Tuna, 2006, "The Implications of Accounting Distortions and Growth for Accruals and Profitability," The Accounting Review, forthcoming.

Sloan, R., 1996, "Do Stock Prices Fully Reflect Information in Accruals and Cash Flows about Future Earnings?," The Accounting Review 71, 289-315.

Shyam-Sunder, and L., Myers, S.C., 1999, “Testing Static Tradeoff against Pecking Order Models of Capital Structure," Journal of Financial Economics 51, 219-244.

Zach, T., 2003, "Inside the 'Accrual Anomaly'," Working Paper, Washington University. 


\section{Appendix: Variable Definitions}

\begin{tabular}{|c|c|}
\hline$\triangle X F I N$ & $\begin{array}{l}\text { Net amount of cash flows received from external financing activities, defined } \\
\text { as } \triangle E Q U I T Y+\triangle D E B T \text {. }\end{array}$ \\
\hline$\triangle E Q U I T Y$ & $\begin{array}{l}\text { Net equity financing measured as the proceeds from the sale of common } \\
\text { and preferred stock (COMPUSTAT item \#108) less cash payments for } \\
\text { the purchase of common and preferred stock (COMPUSTAT item } \\
\# 115 \text { ) less cash payments for dividends (COMPUSTAT item \#127). }\end{array}$ \\
\hline$\triangle D E B T$ & $\begin{array}{l}\triangle D E B T \text { is net debt financing measured as the cash proceeds from the } \\
\text { issuance of long-term debt (COMPUSTAT item \#111) less cash } \\
\text { payments for long-term debt reductions (COMPUSTAT item \#114) less } \\
\text { the net changes in current debt (COMPUSTAT item \#301). }\end{array}$ \\
\hline T_ACCR & $\begin{array}{l}\text { Total accruals is defined as the change in non cash assets [(change in } \\
\text { COMPUSTAT item } \# 6 \text { ) less the change in COMPUSTAT item \#1)] less } \\
\text { the change in non-debt liabilities (change in COMPUSTAT item \#181 } \\
\text { less the change in COMPUSTAT item \#9 less the change in } \\
\text { COMPUSTAT item \#34). }\end{array}$ \\
\hline ACCR & $\begin{array}{l}\text { Accruals, defined as the change in current assets (COMPUSTAT item } \\
\# 4 \text { ) less the change in cash (COMPUSTAT item\#1) less the change in } \\
\text { current liabilities (COMPUSTAT item \#5) plus the change in debt in } \\
\text { current liabilities (COMPUSTAT item \#34) less depreciation } \\
\text { (COMPUSTAT item \#14). }\end{array}$ \\
\hline ACCR_CF & $\begin{array}{l}\text { Accruals, defined as earnings before extraordinary items from the } \\
\text { statement of cash flows (COMPUSTAT item \#123) less cash flows from } \\
\text { operations (COMPUSTAT item \#308). }\end{array}$ \\
\hline FCF & $\begin{array}{l}\text { Free cash flows is equal to the difference between income before } \\
\text { extraordinary items (COMPUSTAT item \#18) and total accruals } \\
T A C C R \text {. }\end{array}$ \\
\hline CFO_BS & $\begin{array}{l}\text { Cash flows from operations is operating income after depreciation } \\
\text { (COMPUSTAT item \#178) less ACCR. }\end{array}$ \\
\hline CFO_87 & $\begin{array}{l}\text { Cash flows from operations is cash flows from operations per the } \\
\text { statement of cash flows (COMPUSTAT item } \# 308 \text { ). }\end{array}$ \\
\hline INVEST_BS & $\begin{array}{l}\text { Cash from investing activities, defined as the sum of the proceeds from } \\
\text { sale of PPE (COMPUSTAT item \#107) plus the proceeds from sale of } \\
\text { investments (COMPUSTAT item \#109) less capital expenditures } \\
\text { (COMPUSTAT item \#128) less acquisitions (COMPUSTAT item } \\
\# 129 \text { ) less the increase in investments (COMPUSTAT item \#113). }\end{array}$ \\
\hline INVEST_SCF & $\begin{array}{l}\text { Cash from investing activities, defined as net cash flows from investing } \\
\text { activities per the statement of cash flows (COMPUSTAT item \#311). }\end{array}$ \\
\hline $\mathrm{NI}$ & Income before extraordinary items (COMPUSTAT item \#18). \\
\hline INCOME & Operating income after depreciation (COMPUSTAT item\#178). \\
\hline
\end{tabular}


Figure 1: Mean external financing ranked by total accruals, 1971-2004

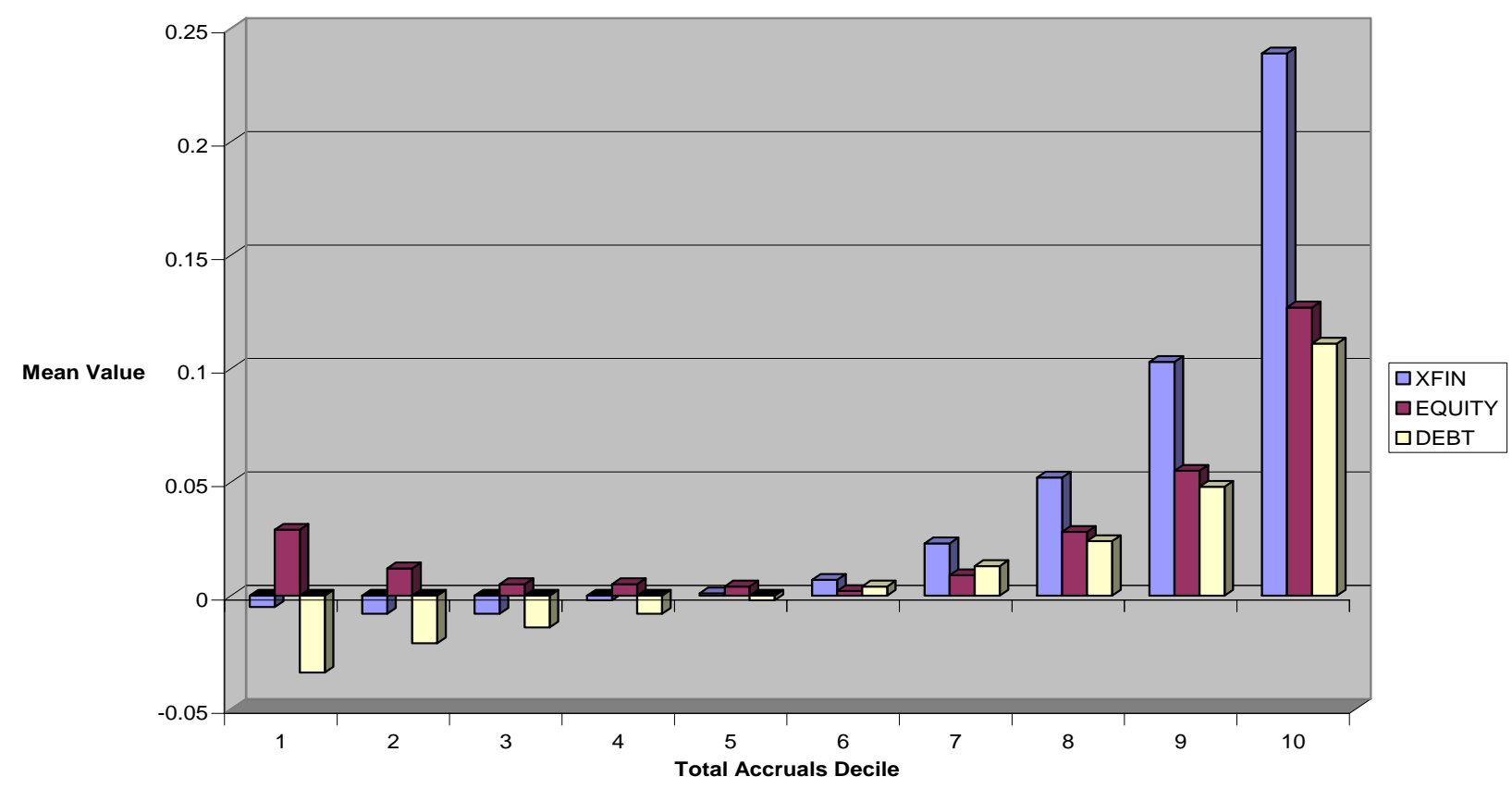

Figure 2: Mean external financing ranked by cash flow statement accruals, 1988-2004

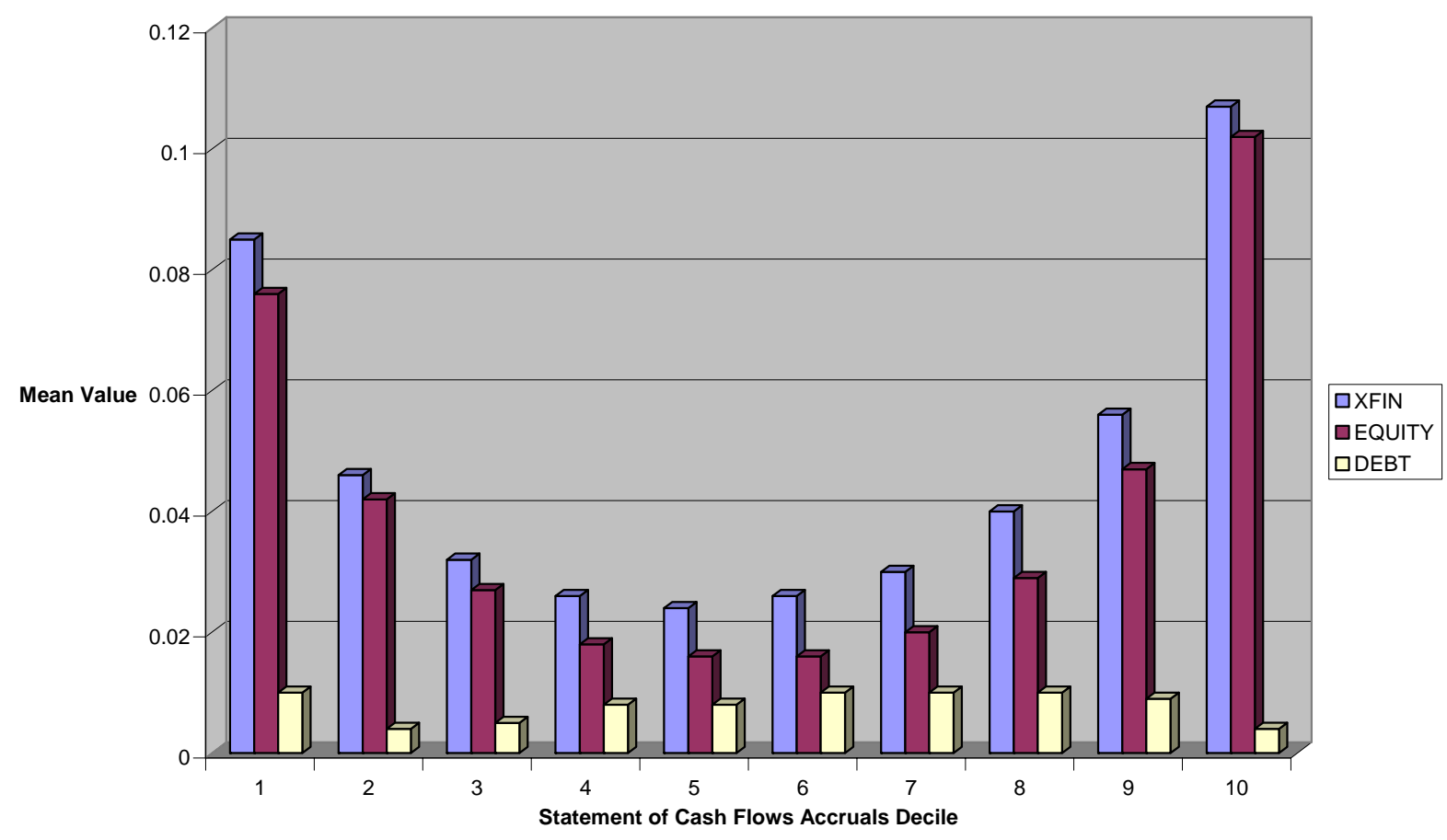


Figure 3: Mean external financing ranked by total accruals, 1988-2004

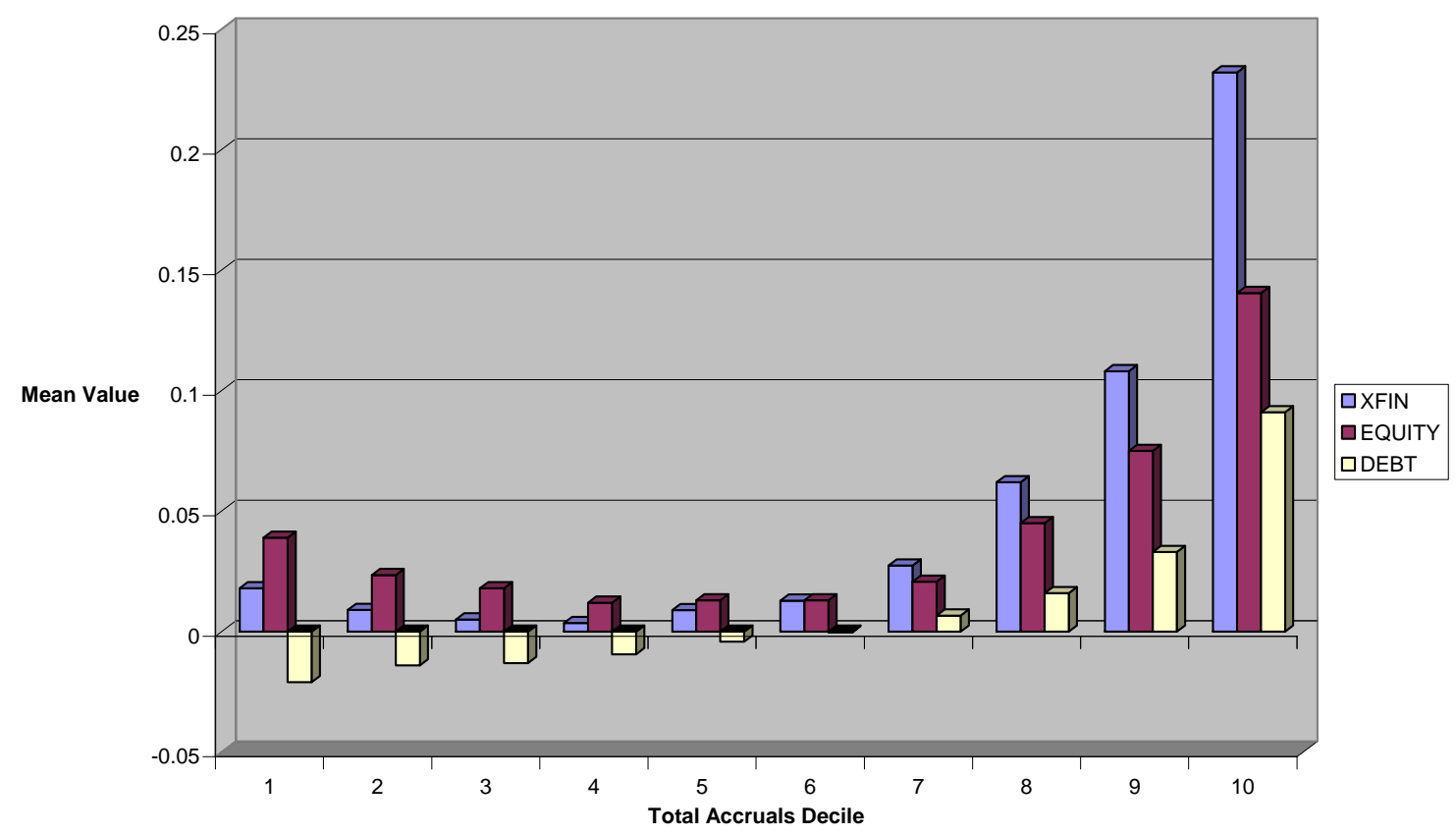

Figure 4: Mean external financing ranked by balance sheet accruals, 1988-2004

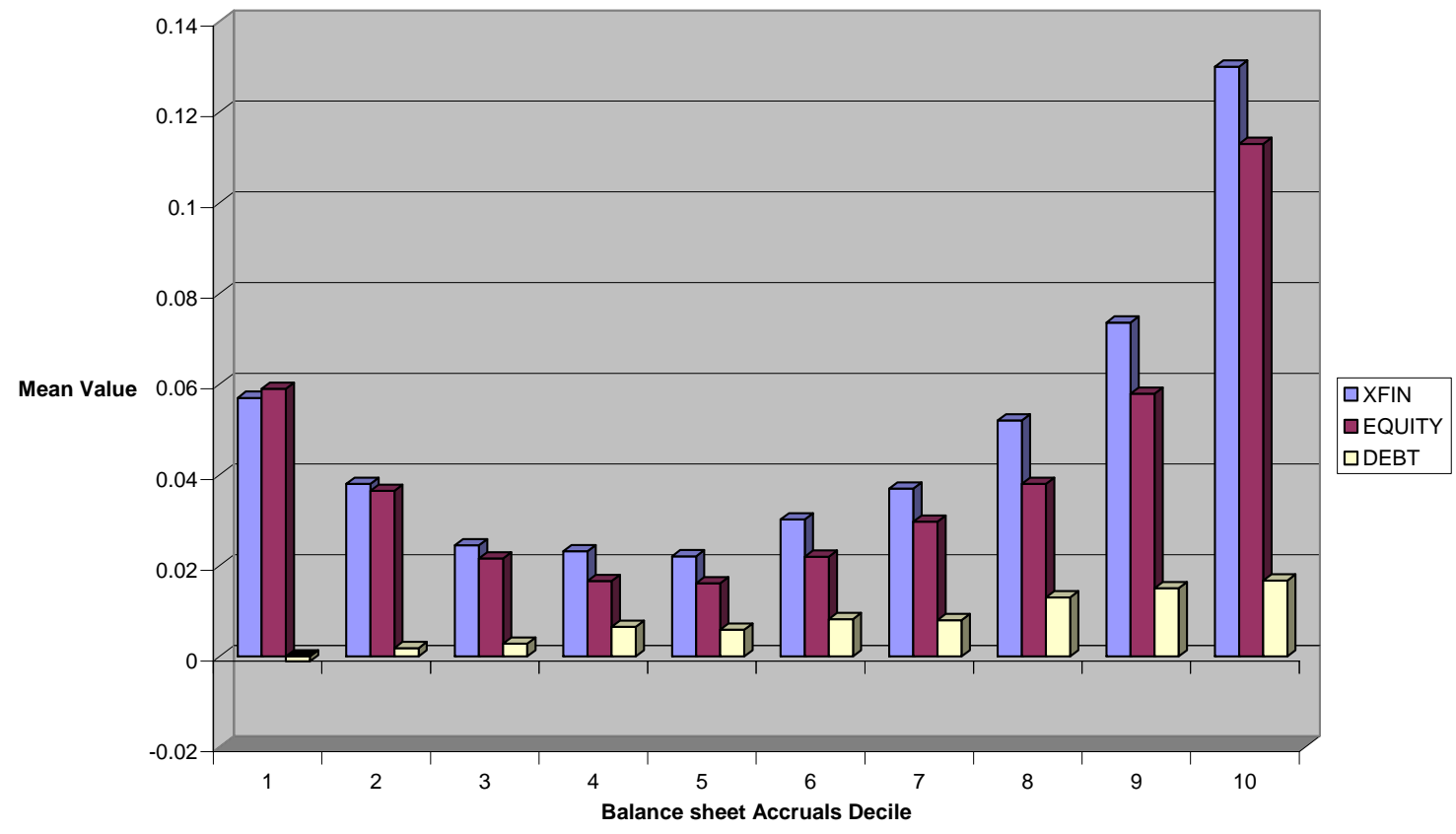


TABLE 1

Univariate statistics and pair-wise correlations for external financing, income, and control variables (1971-2004)

Panel A: Univariate statistics, 1971-2004

\begin{tabular}{ccccccc} 
& $\mathrm{N}$ & Mean & Std. Dev. & $25 \%$ & Median & $75 \%$ \\
\cline { 2 - 7 }$\Delta$ XFIN & 144,025 & 0.041 & 0.184 & -0.040 & 0 & 0.066 \\
$\Delta$ EQUITY & 144,025 & 0.028 & 0.143 & -0.016 & 0 & 0.005 \\
$\Delta$ DEBT & 144,025 & 0.012 & 0.128 & -0.026 & 0 & 0.036 \\
NI & 144,025 & -0.021 & 0.227 & -0.029 & 0.036 & 0.079 \\
T_ACCR & 144,025 & 0.046 & 0.217 & -0.042 & 0.038 & 0.136 \\
ACCR & 144,025 & -0.036 & 0.139 & -0.088 & -0.036 & 0.019 \\
CFO_BS & 144,025 & 0.069 & 0.226 & 0.008 & 0.105 & 0.181 \\
FCF & 144,025 & -0.067 & 0.257 & -0.131 & -0.014 & 0.059
\end{tabular}

Panel B: Univariate statistics, 1988-2004

\begin{tabular}{ccccccc} 
& $\mathrm{N}$ & Mean & Std. Dev. & $25 \%$ & Median & $75 \%$ \\
\cline { 2 - 7 }$\Delta$ XFIN & 78,575 & 0.048 & 0.201 & -0.042 & 0 & 0.076 \\
$\Delta$ EQUITY & 78,575 & 0.040 & 0.163 & -0.010 & 0 & 0.011 \\
$\Delta$ DEBT & 78,575 & 0.008 & 0.134 & -0.032 & 0 & 0.032 \\
NI & 78,575 & -0.056 & 0.261 & -0.076 & 0.022 & 0.071 \\
ACCR_CF & 78,575 & -0.078 & 0.222 & -0.116 & -0.053 & -0.001 \\
CFO_87 & 78,575 & 0.020 & 0.205 & -0.025 & 0.059 & 0.124 \\
FCF & 78,575 & -0.094 & 0.291 & -0.166 & -0.025 & 0.055 \\
T_ACCR & 78,575 & 0.037 & 0.234 & -0.055 & 0.029 & 0.133 \\
ACCR & 78,575 & -0.046 & 0.144 & -0.096 & -0.041 & 0.010
\end{tabular}


Panel C: Pair-wise correlations - Pearson (above diagonal) and Spearman (below diagonal), 1971-2004

\begin{tabular}{ccccccccc} 
& $\Delta$ XFIN & $\Delta$ EQUITY & $\Delta$ DEBT & NI & T_ACCR & ACCR & FCF & CFO_BS \\
\cline { 2 - 8 }$\Delta$ XFIN & - & $0.721^{*}$ & $0.626^{*}$ & $-0.209^{*}$ & $0.346^{*}$ & $0.129^{*}$ & $-0.486^{*}$ & $-0.287^{*}$ \\
$\Delta$ EQUITY & $0.507^{*}$ & - & $-0.089^{*}$ & $-0.259^{*}$ & $0.174^{*}$ & $0.079^{*}$ & $-0.381^{*}$ & $-0.312^{*}$ \\
$\Delta$ DEBT & $0.712^{*}$ & $-0.042^{*}$ & - & $-0.008^{*}$ & $0.301^{*}$ & $0.096^{*}$ & $-0.269^{*}$ & $-0.060^{*}$ \\
NI & $-0.148^{*}$ & $-0.304^{*}$ & $0.013^{*}$ & - & $0.349^{*}$ & $0.333^{*}$ & $0.577^{*}$ & $0.689^{*}$ \\
T_ACCR & $0.353^{*}$ & $0.099^{*}$ & $0.304^{*}$ & $0.372^{*}$ & - & $0.610^{*}$ & $-0.562^{*}$ & $-0.076^{*}$ \\
ACCR & $0.149^{*}$ & $0.033^{*}$ & $0.126^{*}$ & $0.303^{*}$ & $0.634^{*}$ & - & $-0.233^{*}$ & $-0.318^{*}$ \\
FCF & $-0.508^{*}$ & $-0.365^{*}$ & $-0.312^{*}$ & $0.327^{*}$ & $-0.636^{*}$ & $-0.357^{*}$ & - & $0.678^{*}$ \\
CFO_BS & $-0.281^{*}$ & $-0.336^{*}$ & $-0.091^{*}$ & $0.596^{*}$ & $-0.121^{*}$ & $-0.381^{*}$ & $0.613^{*}$ & -
\end{tabular}

Panel D: Pair-wise correlations - Pearson (above diagonal) and Spearman (below diagonal), 1988-2004

\begin{tabular}{cccccccccc} 
& $\Delta$ XFIN & $\Delta$ EQUITY & $\Delta$ DEBT & NI & ACCR_CF & CFO_87 & FCF & T_ACCR & ACCR \\
\cline { 2 - 8 }$\Delta$ XFIN & - & $0.747^{*}$ & $0.589^{*}$ & $-0.225^{*}$ & $-0.009^{*}$ & $-0.278^{*}$ & $-0.434^{*}$ & $0.277^{*}$ & $0.081^{*}$ \\
$\Delta$ EQUITY & $0.536^{*}$ & - & $-0.096^{*}$ & $-0.262^{*}$ & -0.003 & $-0.331^{*}$ & $-0.378^{*}$ & $0.167^{*}$ & $0.073^{*}$ \\
$\Delta$ DEBT & $0.682^{*}$ & $-0.046^{*}$ & - & $-0.018^{*}$ & $-0.010^{*}$ & $-0.013^{*}$ & $-0.191^{*}$ & $0.213^{*}$ & $0.031^{*}$ \\
NI & $-0.165^{*}$ & $-0.261^{*}$ & $-0.007^{* *}$ & - & $0.615^{*}$ & $0.732^{*}$ & $0.634^{*}$ & $0.341^{*}$ & $0.323^{*}$ \\
ACCR_CF & $0.034^{*}$ & $-0.007^{* *}$ & $0.025^{*}$ & $0.418^{*}$ & - & $-0.085^{*}$ & $0.177^{*}$ & $0.470^{*}$ & $0.602^{*}$ \\
CFO_87 & $-0.239^{*}$ & $-0.322^{*}$ & $-0.031^{*}$ & $0.639^{*}$ & $-0.279^{*}$ & - & $0.652^{*}$ & $0.021^{*}$ & $-0.105^{*}$ \\
FCF & $-0.441^{*}$ & $-0.373^{*}$ & $-0.211^{*}$ & $0.404^{*}$ & $-0.098^{*}$ & $0.578^{*}$ & - & $-0.510^{*}$ & $-0.171^{*}$ \\
T_ACCR & $0.277^{*}$ & $0.123^{*}$ & $0.198^{*}$ & $0.375^{*}$ & $0.512^{*}$ & $-0.016^{*}$ & $-0.568^{*}$ & - & $0.573^{*}$ \\
ACCR & $0.100^{*}$ & $0.062^{*}$ & $0.053^{*}$ & $0.302^{*}$ & $0.732^{*}$ & $-0.236^{*}$ & $-0.281^{*}$ & $0.599^{*}$ & -
\end{tabular}

* significant at 0.01 level; ** significant at 0.5 level; $\triangle \mathrm{XFIN}$ is net external financing, calculated as the sum of $\triangle \mathrm{EQUITY}$ and $\triangle \mathrm{DEBT}$. $\triangle \mathrm{EQUITY}$ is net equity financing measured as the proceeds from the sale of common and preferred stock (COMPUSTAT item \#108) less cash payments for the purchase of common and preferred stock (COMPUSTAT item \#115) less cash payments for dividends (COMPUSTAT item \#127). $\triangle \mathrm{DEBT}$ is net debt financing measured as the cash proceeds from the issuance of long-term debt (COMPUSTAT item \#111) less cash payments for long-term debt reductions (COMPUSTAT item \#114) less the net changes in current debt (COMPUSTAT item \#301). NI is income before extraordinary items (COMPUSTAT item \#18). T_ACCR is total accruals defined as the change in non cash assets [(change in COMPUSTAT item \#6) less the change in COMPUSTAT item \#1)] less the change in non-debt liabilities [change in COMPUSTAT item \#181 less the change in COMPUSTAT item \#9 less the change in COMPUSTAT item \#34]. ACCR is the change in current assets (COMPUSTAT item \#4) less the change in cash (COMPUSTAT item \#1) less the change in current liabilities (COMPUSTAT item \#5) plus the change in debt in current liabilities (COMPUSTAT item \#34) less depreciation (COMPUSTAT item \#14). ACCR_CF is accruals from the cash flow statement, defined as earnings before extraordinary items (COMPUSTAT item \#123) less cash flows from operations (COMPUSTAT item \#308). CFO_BS is operating income after depreciation (COMPUSTAT item \#178) less ACCR. CFO_87 is cash flows from operations per the cash flow statement (COMPUSTAT item \#308). FCF is free cash flows, defined as net income less T_ACCR (total accruals). All variables are scaled by average total assets (COMPUSTAT item \#6). 
TABLE 2

Mean (Medians) for various variables partitioned by deciles of various measures of accruals

Panel A: Sample period: 1971-2004, partitioned by T_ACCR (total accruals)

\begin{tabular}{lcccccccccc} 
& LOW & $\mathbf{2}$ & $\mathbf{3}$ & $\mathbf{4}$ & $\mathbf{5}$ & $\mathbf{6}$ & $\mathbf{7}$ & $\mathbf{8}$ & $\mathbf{9}$ & HIGH \\
\cline { 2 - 5 } & -0.005 & -0.008 & -0.008 & -0.002 & 0.001 & 0.007 & 0.023 & 0.052 & 0.103 & 0.239 \\
& $(-0.006)$ & $(-0.019)$ & $(-0.022)$ & $(-0.019)$ & $(-0.015)$ & $(-0.009)$ & $(0)$ & $(0.016)$ & $(0.065)$ & $(0.206)$ \\
$\Delta$ EQUITY & 0.029 & 0.012 & 0.005 & 0.005 & 0.004 & 0.002 & 0.009 & 0.028 & 0.055 & 0.127 \\
& $(0)$ & $(0)$ & $(0)$ & $(-0.002)$ & $(-0.005)$ & $(-0.005)$ & $(-0.004)$ & $(0)$ & $(0)$ & $(0.008)$ \\
$\Delta$ DEBT & -0.034 & -0.021 & -0.014 & -0.008 & -0.002 & 0.004 & 0.013 & 0.024 & 0.048 & 0.111 \\
& $(-0.008)$ & $(-0.010)$ & $(-0.008)$ & $(-0.004)$ & $(-0.002)$ & $(0)$ & $(0)$ & $(0)$ & $(0.018)$ & $(0.064)$ \\
NI & -0.295 & -0.071 & -0.014 & 0.002 & 0.021 & 0.032 & 0.038 & 0.041 & 0.033 & -0.000 \\
& $(-0.200)$ & $(-0.014)$ & $(0.019)$ & $(0.032)$ & $(0.043)$ & $(0.051)$ & $(0.058)$ & $(0.063)$ & $(0.062)$ & $(0.048)$ \\
T_ACCR & -0.361 & -0.108 & -0.043 & -0.007 & 0.024 & 0.054 & 0.089 & 0.137 & 0.216 & 0.456 \\
& $(-0.292)$ & $(-0.104)$ & $(-0.042)$ & $(-0.006)$ & $(0.024)$ & $(0.054)$ & $(0.089)$ & $(0.136)$ & $(0.212)$ & $(0.403)$ \\
ACCR & $(-0.227)$ & -0.113 & -0.072 & -0.051 & -0.036 & -0.020 & -0.004 & 0.018 & 0.044 & 0.095 \\
& $(-0.204)$ & $-0.112)$ & $(-0.069)$ & $(-0.046)$ & $(-0.031)$ & $(-0.160)$ & $(0)$ & $(0.022)$ & $(0.046)$ & $(0.068)$ \\
CFO_BS & 0.023 & 0.086 & 0.101 & 0.096 & 0.104 & 0.101 & 0.094 & 0.079 & 0.044 & -0.039 \\
& $(0.077)$ & $(0.121)$ & $(0.126)$ & $(0.123)$ & $(0.122)$ & $(0.119)$ & $(0.112)$ & $(0.099)$ & $(0.071)$ & $(0.015)$ \\
FCF & 0.065 & 0.036 & 0.029 & 0.009 & -0.002 & -0.022 & -0.051 & -0.096 & -0.183 & -0.460 \\
& $(0.099)$ & $(0.087)$ & $(0.062)$ & $(0.039)$ & $(0.019)$ & $(-0.003)$ & $(-0.032)$ & $(-0.074)$ & $(-0.151)$ & $(-0.375)$ \\
SIZE & 208.68 & 447.56 & 1023.04 & 1273.94 & 1564.30 & 1413.21 & 1332.47 & 917.28 & 707.57 & 608.91 \\
& $(8.71)$ & $(20.21)$ & $(37.58)$ & $(51.15)$ & $(68.69)$ & $(69.59)$ & $(65.47)$ & $(61.35)$ & $(50.95)$ & $(49.11)$
\end{tabular}

Panel B: Sample period: 1988-2004, partitioned by ACCR_CF (Accruals per cash flow statement)

\begin{tabular}{lcccccccccc} 
& LOW & $\mathbf{2}$ & $\mathbf{3}$ & $\mathbf{4}$ & $\mathbf{5}$ & $\mathbf{6}$ & $\mathbf{7}$ & $\mathbf{8}$ & $\mathbf{9}$ & HIGH \\
\cline { 2 - 11 }$\Delta$ XFIN & 0.085 & 0.046 & 0.032 & 0.026 & 0.024 & 0.026 & 0.030 & 0.040 & 0.056 & 0.107 \\
& $(0.010)$ & $(0)$ & $(-0.002)$ & $(-0.006)$ & $(-0.007)$ & $(-0.007)$ & $(-0.002)$ & $(0)$ & $(0.006)$ & $(0.03)$ \\
$\Delta$ EQUITY & 0.076 & 0.042 & 0.027 & 0.018 & 0.016 & 0.016 & 0.020 & 0.029 & 0.047 & 0.102 \\
& $(0)$ & $(0)$ & $(0)$ & $(0)$ & $(0)$ & $(0)$ & $(0)$ & $(0)$ & $(0)$ & $(0.003)$ \\
$\Delta$ DEBT & 0.010 & 0.004 & 0.005 & 0.008 & 0.008 & 0.010 & 0.010 & 0.010 & 0.009 & 0.004 \\
& $(0)$ & $(0)$ & $(0)$ & $(0)$ & $(-0.006)$ & $(0)$ & $(0)$ & $(0)$ & $(0)$ & $(0)$ \\
NI & -0.499 & -0.121 & -0.038 & -0.006 & 0.007 & 0.014 & 0.017 & 0.019 & 0.026 & 0.024 \\
& $(-0.400)$ & $(-0.073)$ & $(0.008)$ & $(0.023)$ & $(0.030)$ & $(0.034)$ & $(0.039)$ & $(0.040)$ & $(0.048)$ & $(0.060)$ \\
ACCR_CF & -0.450 & -0.176 & -0.117 & -0.085 & -0.063 & -0.044 & -0.024 & -0.001 & 0.037 & 0.164 \\
& $(-0.362)$ & $(-0.172)$ & $(-0.116)$ & $(-0.084)$ & $(-0.063)$ & $(-0.044)$ & $(-0.024)$ & $(-0.001)$ & $(0.035)$ & $(0.130)$ \\
CFO_87 & -0.049 & 0.055 & 0.079 & 0.079 & 0.070 & 0.058 & 0.042 & 0.020 & -0.009 & -0.139 \\
& $(0)$ & $(0.099)$ & $(0.123)$ & $(0.108)$ & $(0.094)$ & $(0.078)$ & $(0.064)$ & $(0.040)$ & $(0.011)$ & $(-0.077)$ \\
T_ACCR & -0.228 & -0.040 & 0.009 & 0.031 & 0.044 & 0.054 & 0.068 & 0.088 & 0.127 & 0.218 \\
& $(-0.246)$ & $(-0.081)$ & $(-0.025)$ & $(-0.003)$ & $(0.013)$ & $(0.025)$ & $(0.041)$ & $(0.059)$ & $(0.100)$ & $(0.204)$ \\
ACCR & -0.226 & -0.125 & -0.091 & -0.067 & -0.052 & -0.036 & -0.019 & -0.001 & 0.032 & 0.126 \\
& $(-0.217)$ & $(-0.135)$ & $(-0.097)$ & $(-0.072)$ & $(-0.054)$ & $(-0.037)$ & $(-0.020)$ & $(0)$ & $(0.036)$ & $(0.117)$ \\
SIZE & 198.54 & 760.05 & 1419.90 & 2317.79 & 2763.26 & 2906.85 & 2141.03 & 1394.21 & 728.06 & 294.43 \\
& $(12.49)$ & $(32.87)$ & $(70.89)$ & $(113.78)$ & $(154.46)$ & $(169.79)$ & $(147.12)$ & $(101.25)$ & $(72.29)$ & $(39.312)$
\end{tabular}


Notes Table 2: $\triangle \mathrm{XFIN}$ is net external financing, calculated as the sum of $\triangle \mathrm{EQUITY}$ and $\triangle \mathrm{DEBT}$. $\triangle \mathrm{EQUITY}$ is net equity financing measured as the proceeds from the sale of common and preferred stock (COMPUSTAT item \#108) less cash payments for the purchase of common and preferred stock (COMPUSTAT item \#115) less cash payments for dividends (COMPUSTAT item \#127). $\triangle \mathrm{DEBT}$ is net debt financing measured as the cash proceeds from the issuance of long-term debt (COMPUSTAT item \#111) less cash payments for long-term debt reductions (COMPUSTAT item \#114) less the net changes in current debt (COMPUSTAT item \#301). NI is income before extraordinary items (COMPUSTAT item \#18). T_ACCR is total accruals defined as the change in non cash assets [(change in COMPUSTAT item \#6) less the change in COMPUSTAT item \#1)] less the change in non-debt liabilities [change in COMPUSTAT item \#181 less the change in COMPUSTAT item \#9 less the change in COMPUSTAT item \#34]. ACCR is the change in current assets (COMPUSTAT item \#4) less the change in cash (COMPUSTAT item\#1) less the change in current liabilities (COMPUSTAT item \#5) plus the change in debt in current liabilities (COMPUSTAT item \#34) less depreciation (COMPUSTAT item \#14). ACCR_CF is accruals from the cash flow statement, defined as earnings before extraordinary items (COMPUSTAT item \#123) less cash flows from operations (COMPUSTAT item \#308). CFO_BS is operating income after depreciation (COMPUSTAT item \#178) less ACCR. CFO_87 is cash flows from operations per the cash flow statement (COMPUSTAT item \#308). FCF is free cash flows, defined as net income less T_ACCR (total accruals). SIZE is market value of equity defined as COMPUSTAT item \#199 times COMPUSTAT item \#25. 
TABLE 3

Time-series means and t-statistics for coefficients from annual cross-sectional regressions of future stock returns on change in external financing and total accruals

\section{Panel A: Net external financing and total accruals}

$\begin{array}{ccccc}\mathbf{S R E T}_{\mathbf{t}+\mathbf{1}}=\gamma_{\mathbf{0}}+\gamma_{\mathbf{1}} \Delta \mathbf{X F I N} \mathbf{t}+\gamma_{\mathbf{2}} \mathbf{T}_{\mathbf{C}} \mathbf{A C C R _ { \mathbf { t } } + \mathbf { v } _ { \mathbf { t } + \mathbf { 1 } }} & & \\ & \gamma_{0} & \gamma_{1} & \gamma_{2} & \text { Adj. } \mathbf{R}^{2} \\ \text { Coefficient } & 0.058 & -0.192 & & 0.007 \\ \text { (t-statistic) } & 1.89 & -4.92 & & \\ & & & & \\ \text { Coefficient } & 0.065 & & -0.260 & 0.007 \\ \text { (t-statistic) } & 2.09 & & -6.36 & \\ & & & & \\ \text { Coefficient } & 0.067 & -0.081 & -0.216 & 0.010 \\ \text { (t-statistic) } & 2.18 & -1.49 & -4.40 & \end{array}$

Panel B: Debt and equity components of net external financing and total accruals

\begin{tabular}{|c|c|c|c|c|c|}
\hline & $\gamma_{0}$ & $\gamma_{1}$ & $\gamma_{2}$ & $\gamma_{3}$ & Adj. $\mathrm{R}^{2}$ \\
\hline $\begin{array}{l}\text { Coefficient } \\
\text { (t-statistic) }\end{array}$ & $\begin{array}{c}0.052 \\
1.66\end{array}$ & $\begin{array}{c}-0.187 \\
-5.63\end{array}$ & & & 0.0012 \\
\hline $\begin{array}{l}\text { Coefficient } \\
\text { (t-statistic) }\end{array}$ & $\begin{array}{c}0.054 \\
1.78\end{array}$ & & $\begin{array}{l}-0.152 \\
-2.02\end{array}$ & & 0.008 \\
\hline $\begin{array}{l}\text { Coefficient } \\
\text { (t-statistic) }\end{array}$ & $\begin{array}{c}0.058 \\
1.90\end{array}$ & $\begin{array}{c}-0.203 \\
-6.27\end{array}$ & $\begin{array}{l}-0.167 \\
-2.22\end{array}$ & & 0.008 \\
\hline $\begin{array}{l}\text { Coefficient } \\
\text { (t-statistic) }\end{array}$ & $\begin{array}{c}0.067 \\
2.19\end{array}$ & $\begin{array}{c}-0.064 \\
-1.71\end{array}$ & $\begin{array}{c}-0.081 \\
-0.98\end{array}$ & $\begin{array}{l}-0.216 \\
-4.62\end{array}$ & 0.012 \\
\hline
\end{tabular}

Notes Table 3: Reported regression coefficients are mean coefficients from 33 annual regressions. SRET is the annual buy and hold stock return calculated starting four months after the fiscal year-end, less the corresponding return on the value weighted CRSP index.

$\triangle \mathrm{XFIN}$ is net external financing, calculated as the sum of $\triangle \mathrm{EQUITY}$ and $\triangle \mathrm{DEBT}$. $\triangle \mathrm{EQUITY}$ is net equity financing measured as the proceeds from the sale of common and preferred stock (COMPUSTAT item \#108) less cash payments for the purchase of common and preferred stock (COMPUSTAT item \#115) less cash payments for dividends (COMPUSTAT item \#127). $\triangle \mathrm{DEBT}$ is net debt financing measured as the cash proceeds from the issuance of long-term debt (COMPUSTAT item \#111) less cash payments for longterm debt reductions (COMPUSTAT item \#114) less the net changes in current debt (COMPUSTAT item \#301). All external financing and income variables are deflated by average total assets. T_ACCR is total accruals defined as the change in non cash assets [(change in COMPUSTAT item \#6) less the change in COMPUSTAT item \#1)] less the change in non-debt liabilities [change in COMPUSTAT item \#181 less the change in COMPUSTAT item \#9 less the change in COMPUSTAT item \#34]. 
TABLE 4

Summary statistics of regressions of future operating income on operating income and change in external financing, investments, and cash flows

Panel A: Net external financing

\begin{tabular}{|c|c|c|c|c|}
\hline & $\gamma_{0}$ & $\gamma_{1}$ & $\gamma_{2}$ & Adj. $\mathrm{R}^{2}$ \\
\hline $\begin{array}{l}\text { Coefficient } \\
\text { (t-statistic) }\end{array}$ & $\begin{array}{l}0.029 \\
(6.38)\end{array}$ & $\begin{array}{c}0.437 \\
(33.11)\end{array}$ & $\begin{array}{l}-0.055 \\
(-8.54)\end{array}$ & 0.287 \\
\hline
\end{tabular}

Panel B: Debt and equity components of net external financing

\begin{tabular}{lccccc}
\multicolumn{5}{c}{$I N C O M E_{\mathrm{t}+2, \mathrm{t}+5}=$} & $\gamma_{0}+\gamma_{1} I N C O M E_{t}+\gamma_{2} \Delta E Q U T Y_{t}+\gamma_{3} \Delta D E B T_{t}+v_{t+1}$ \\
& $\gamma_{0}$ & $\gamma_{1}$ & $\gamma_{2}$ & $\gamma_{3}$ & Adj. $\mathrm{R}^{2}$ \\
\cline { 2 - 6 } Coefficient & 0.029 & 0.428 & -0.114 & & 0.292 \\
(t-statistic) & $(6.61)$ & $(32.25)$ & $(-13.12)$ & & \\
Coefficient & 0.026 & 0.446 & & 0.002 & 0.281 \\
(t-statistic) & $(5.54)$ & $(31.92)$ & & $(0.43)$ & \\
Coefficient & 0.029 & 0.427 & -0.115 & -0.006 & 0.292 \\
(t-statistic) & $(6.60)$ & $(32.35)$ & $(-13.03)$ & $(-1.26)$ &
\end{tabular}

Panel C: Investments and Cash from Operations (1971-2004)

\begin{tabular}{|c|c|c|c|c|c|}
\hline & $\gamma_{0}$ & $\gamma_{1}$ & $\gamma_{2}$ & $\gamma_{3}$ & Adj. $\mathrm{R}^{2}$ \\
\hline Coefficient & 0.027 & 0.446 & -0.005 & & 0.283 \\
\hline (t-statistic) & $(5.42)$ & (32.51) & $(-0.54)$ & & $0.20 J$ \\
\hline Coefficient & 0.023 & 0.374 & & 0.091 & 0.289 \\
\hline (t-statistic) & $(4.54)$ & (31.23) & & $(9.37)$ & 0.209 \\
\hline Coefficient & 0.023 & 0.374 & -0.007 & 0.092 & 0.293 \\
\hline t-statistic) & $(4.48)$ & (31.80) & $(-0.71)$ & $(9.57)$ & \\
\hline
\end{tabular}

Panel D: Investments and Cash from Operations (1988-2004)

\begin{tabular}{lccccc}
\multicolumn{5}{c}{$I N C O M E_{\mathrm{t}+2, \mathrm{t}+5}=$} & $\gamma_{0}+\gamma_{1} I N C O M E_{t}+\gamma_{2} \Delta I N V_{-} S C F_{t}+\gamma_{3} C F O_{t}+v_{t+1}$ \\
& $\gamma_{0}$ & $\gamma_{1}$ & $\gamma_{2}$ & $\gamma_{3}$ & Adj. $\mathrm{R}^{2}$ \\
\cline { 2 - 6 } Coefficient & 0.006 & 0.516 & 0.011 & & 0.338 \\
(t-statistic) & $(1.79)$ & $(31.72)$ & $(1.41)$ & & \\
Coefficient & 0.005 & 0.461 & & 0.091 & 0.339 \\
(t-statistic) & $(1.71)$ & $(31.05)$ & & $(7.72)$ & \\
Coefficient & 0.006 & 0.461 & -0.003 & 0.093 & 0.341 \\
(t-statistic) & $(1.65)$ & $(30.19)$ & $(-0.33)$ & $(7.51)$ &
\end{tabular}




\section{Panel E: Investments, Cash from Operations (1971-2004), Debt and equity components of net external financing}

$$
I N C O M E_{\mathrm{t}+2, \mathrm{t}+5}=\gamma_{0}+\gamma_{1} I N C O M E_{t}+\gamma_{2} \Delta E Q U T Y_{t}+\gamma_{3} \Delta D E B T_{t}+\gamma_{4} \Delta I N V_{-} B S_{t}+\gamma_{5} C F O_{t}+v_{t+1}
$$

\begin{tabular}{lccccccc} 
& $\gamma_{0}$ & $\gamma_{1}$ & $\gamma_{2}$ & $\gamma_{3}$ & $\gamma_{4}$ & $\gamma_{5}$ & Adj. R $^{2}$ \\
\cline { 2 - 7 } Coefficient & 0.028 & 0.424 & -0.120 & -0.015 & 0.023 & & 0.294 \\
(t-statistic) & $(5.78)$ & $(33.81)$ & $(-14.42)$ & $(-3.17)$ & $(2.26)$ & & \\
Coefficient & 0.026 & 0.372 & -0.101 & 0.001 & & 0.074 & 0.299 \\
(t-statistic) & $(5.58)$ & $(31.60)$ & $(-10.88)$ & $(0.36)$ & & $(8.51)$ & \\
Coefficient & 0.025 & 0.369 & -0.103 & -0.000 & 0.012 & 0.074 & 0.301 \\
(t-statistic) & $(4.99)$ & $(31.68)$ & $(-11.37)$ & $(-0.10)$ & $(1.07)$ & $(8.52)$ &
\end{tabular}

\section{Panel F: Investments, Cash from Operations (1988-2004), Debt and equity components of net external financing}

$$
I N C O M E_{\mathrm{t}+2, \mathrm{t}+5}=\gamma_{0}+\gamma_{1} I N C O M E_{t}+\gamma_{2} \Delta E Q U T Y_{t}+\gamma_{3} \Delta D E B T_{t}+\gamma_{4} \Delta I N V_{-} S C F_{t}+\gamma_{5} C F O_{t}+v_{t+1}
$$

\begin{tabular}{lccccccc} 
& $\gamma_{0}$ & $\gamma_{1}$ & $\gamma_{2}$ & $\gamma_{3}$ & $\gamma_{4}$ & $\gamma_{5}$ & Adj. R $^{2}$ \\
\cline { 2 - 7 } Coefficient & 0.007 & 0.478 & -0.137 & -0.030 & 0.060 & & 0.353 \\
(t-statistic) & $(2.21)$ & $(30.69)$ & $(-14.94)$ & $(-4.21)$ & $(7.02)$ & & \\
Coefficient & 0.009 & 0.457 & -0.100 & 0.001 & & 0.063 & 0.348 \\
(t-statistic) & $(2.94)$ & $(30.40)$ & $(-11.85)$ & $(0.15)$ & & $(5.46)$ & \\
Coefficient & 0.007 & 0.455 & -0.120 & -0.021 & 0.044 & 0.047 & 0.351 \\
(t-statistic) & $(2.14)$ & $(29.31)$ & $(-10.58)$ & $(-2.71)$ & $(4.04)$ & $(3.76)$ &
\end{tabular}

\footnotetext{
Notes Table 4: INCOME is operating income after deprecation (COMPUSTAT item \#178).
}

$\mathrm{INCOME}_{\mathrm{t}+2, \mathrm{t}+5}$ is average income for the 4 year period starting one full year after the external financing period. $\triangle X F I N$ is net external financing, calculated as the sum of $\triangle E Q U T Y$ and $\triangle D E B T$. $\triangle E Q U T Y$ is net equity financing measured as the proceeds from the sale of common and preferred stock (COMPUSTAT item \#108) less cash payments for the purchase of common and preferred stock (COMPUSTAT item \#115) less cash payments for dividends (COMPUSTAT item \#127). $\triangle D E B T$ is net debt financing measured as the cash proceeds from the issuance of long-term debt (COMPUSTAT item \#111) less cash payments for long-term debt reductions (COMPUSTAT item \#114) less the net changes in current debt (COMPUSTAT item \#301). $\triangle D E B T / \triangle X F I N$ is the percentage of $\triangle \mathrm{DEBT}$ out of total net external financing. Income is operating income after depreciation (COMPUSTAT item \#178). CFO is cash flow from operation: if the observation is before 1987, this is CFO_BS which is operating income after depreciation (COMPUSTAT item \#178) less ACCR. If the observation is post 1987, then CFO is CFO_87 which is cash flow from operations per the cash flow statement (COMPUSTAT item\#308).

$I N V_{-} B S$ is defined as the sum of proceeds from sale of PPE (COMPUSTAT item \#107) plus the proceeds from sale of investments (COMPUSTAT item \#109) less capital expenditures (COMPUSTAT item \#128) less acquisitions (COMPUSTAT item \#129) less the increase in investments (COMPUSTAT item \#113). INVEST_SCF is net cash flows from investing activities per the statement of cash flows (COMPUSTAT item \#31). All variables are deflated by average total assets (COMPUSTAT item \#6).

The table reports mean coefficients from 30 annual regressions using the Fama-Macbeth (1973) procedure. 